\title{
DIFFERENCES IN THE STRUCTURAL RESPONSE OF 'GRANNY-SMITH' APPLES UNDER MECHANICAL IMPACT AND COMPRESSION
}

\author{
L. RODRIGUEZ \\ Instituto del Frio (C.S.I.C.) \\ Cuidad Universitaria, 28040 Madrid (Spain) \\ and \\ M. RUIZ \\ Departanento de Ingenieria Rural (E.T.S.I. Agronomos) \\ Ciudad Universitaria, 28040 Madrid (Spain) \\ and \\ M. R. DE FELIPE \\ Instituto de Edafologia y Biologia Vegetal (C.S.I.C.) \\ Serrano 115, 2806 Madrid (Spain) \\ (Manuscript received July 26, 1989; in final furm February 26, 1990)
}

\begin{abstract}
Apple fruits, cv. Granny Smith, were subjected to mechanical impact and compression loads utilizing a steel rod with a spherical tip $19 \mathrm{~mm}$ diameter. $50.6 \mathrm{~g}$ mass. Energies applied were low enough to produce enzymatic reaction: $0.0120 \mathrm{~J}$ for impact, and $0.0199 \mathrm{~J}$ for compression. Bruised material was cut and examined with a transmission electron microscope. In both compression and impact, bruises showed a central region located in the flesh parenchyma, at a distance that approximately equalled the indentor tip radius. The parenchyma cells of this region were more altered than cells from the epidermis and hypodermis. Tissues under compression presented numerous deformed parenchyma cells with broken tonoplasts and tissue degradation as predicted by several investigators. The impacted cells supported different kinds of stresses than compressed cells, resulting in tho formation of intensive vesiculation, either in the vacuole or in the middle lamella region between cell walls of adjacent cells. A
\end{abstract}

Journal of Texture Studies 21 (1990) 155-164. All Rights Reserved.

(C) Copyright 1990 by Food \& Nutrition Press, Inc.. Trumbull, Connecticut. 
large proportion of parenchyma cells completely split or had initiated splitting at the middle lamella. Bruising may develop with or without cell rupture. Therefore, cell wall rupture is not essential for the development of a bruise, at least the smallest one, as predicted previously?

\section{INTRODUCTION}

In recent years, several studies (Chen et al. 1986; Diehl et al. 1979; Garcia 1988; Holt and Schoorl 1977a; Topping and Luton 1986) have been carried out to investigate the appearance and development of fruit bruises. The study of bruises incurred by compression and impact damage in fruit harvesting, handling, packaging and transport operations is necessary from the point of view of market quality in fresh fruits.

Bruising develops in the fruit after a mechanical load is applied, and is evaluated by the amount of tissue softening and discoloration (Coombe 1976). Cellular softening is accomplished by polygalacturonases, pectinmethylesterases, and cellulases degrading cell wall material (Ben Arie and Naomi 1979). The browning reaction is an oxidative reaction, in which the polyphicnoloxidases oxidize phenolic compounds to quinones that are unstable and polymerize as melanic compounds with a high molecular weight (Vamos-Vigyazo 1981).

The site where the browning reaction takes place and the way the cells respond to applied loads have not yet been completely clarified.

Polyphenols are located primarily in the vacuole and polyphenoxidases in the chloroplasts (Vamos-Vigyazo 1981). Diehl et al. (1979), and Pitt (1982) reported that the oxidative reaction develops in the intercellular spaces after cell rupture occurs due to mechanical action; on the other hand, Faust and Shear (1968) and Shoei (1984) stated that the browning reaction occurs in the cytoplasm.

Few attempts have been made to study the internal features of the bruise, mainly because it is very difficult to cut and to fix bruises. Scanning electron microscopy microphotographs of 'Granny Smith' and 'Golden Delicious' apple bruises, produced by mechanical impact and compression conditions, showed several fracture layers. These layers appeared in areas where the maximum stress was applied (Jarymopas 1984). Bruises of pears cv. Anjou presented an outer region beneath the epidermis less damaged than the central part (O'Brien et al. 1983).

Generally, bruise evaluation encompasses direct visual characteristics, such as presence of discontinuities or fractures, and shape and size (Chen et al. 1986; Garcia 1988; Garcia et al. 1988; Holt and Schoorl 1977 a,b; Hyde and Ingle 1968; Rodriguez 1988; Topping and Luton 1986). Bruises caused by impact generally are smaller than those caused by compression loads (Chen et al. 1986; Garcia 1988; Rodriguez 1988). Discontinuities and fractures always appeared some millimeters below the skin, where the maximum stress and/or strain is thought to occur. The stress and maximum deformation are greatest slightly beneath the epidermis located in an area that approximately equals the radius of the indentor used to damage the fruit (Horsfield et al. 1972; Miles and Rehkugler 1971).

To date, several models have been suggested to explain the internal response of fruit under applied loads and strains (Chen et al. 1986; Dal Fabro et al. 1980; Holt and Schoorl 1977b; Nilsson et al. 1958; Pitt 1982; Segerlind and Dal Fabro 1978), but none of them is based on histological studies. Holt and Schoorl (1977b) postulated that under slow strain rates (compression) the sinuous microfibrils straighten and then slip around each other. Bruising is caused by cells bursting when the flesh is compressed. Under dynamic conditions (impact), however, they straighten out and snap, much as a slack rope does when it is sudderily loaded. More energy is thus dissipated in breaking microfibrils and hence bruising is decreased.

The purpose of this work is to use histological techniques, based on transmission electron microscopy, to examine the validity of current predictions in bruise formation. The specific objectives were (1) to ascertain the site where the browning reaction takes place in bruises produced by low energy impact and compression loads where no discontinuities or fractures are produced, (2) to observe the differences in the internal structure of bruises caused by impact and compression, and (3) to try to verify "in situ" the models suggested in bruise development.

\section{MATERIALS AND METHODS}

Three apple fruits, cv. Granny Smith were selected from several bought in a central market, with maturity stage given by a range of firmness between 22 $25 \mathrm{~N}$ (Magness-Tayior assay) and with soluble solid content of $12.5-14.0^{\circ} \mathrm{Brix}$. Fruits were subjected to the impact and compression conditions with three replicates on each fruit.

Energies applied were at the lowest values, previously observed, where bruise discoloration was distinguishable: $0.00120 \mathrm{~J}$ for impact and $0.0199 \mathrm{~J}$ for compression. Loads were applied using a steel rod indentor of $50.6 \mathrm{~g}$ mass, with a spherical tip (19 mm diameter). The indentor was coated with ink to show the contact area where the bruise developed.

Under impact conditions, the indentor was dropped from a height of $4 \mathrm{~cm}$. In the compression experiment, the indentor was fitted to the mobile head of an Instron Universal Testing Machine, Model 1122, with a full scale load setting of $100 \mathrm{~N}$, a crosshead speed of $10 \mathrm{~mm} / \mathrm{min}$ and a maximum deformation of $15 \mathrm{~mm}$. 
After impact or slow compression, the apples were allowed to stand for $2 \mathrm{~h}$ to allow discoloration to take place in the bruise region. A longitudinal sector including the center of the bruise region was then removed, and thin transverse slices were cut in three different regions of the sector, the first right beneath the epidermis, the second containing parenchyma cells from the central part of the bruise, and the third including parenchyma cells adjacent to damaged cells from the central area. Slices were fixed in $3 \%(\mathrm{v} / \mathrm{v})$ glutaraldehyde in $0.05 \mathrm{M} \mathrm{Na}$ cacodylate $(\mathrm{pH} 7,4)$ for $3 \mathrm{~h}$ at $4{ }^{\circ} \mathrm{C}$, and postfixed in a buffered $2 \% \mathrm{OsO}_{4}$ for 2 h. After acetone dehydration, tissues were embedded in Araldite (Durcupan $\mathrm{ACM}$ ), following conventional methods. Ultrathin sections were cut with a diamond knife (Dupont 32525) fitted to a Reichert Om U2 ultramicrotome, poststained with lead citrate (Reynolds 1963), and later examined in three different regions with a transmission electron microscope, Phillips 300 at $60 \mathrm{Kv}$.

\section{RESULTS}

Cells of normal apple tissue at this maturity stage showed, in some areas, a lack of cell wall microfibrillar compactness, middle lamella degradation, and the presence of chromoplasts containing considerable numbers of plastoglobules (Fig. 1A and 1C), but other cells showed a clear network of microfibrils (Fig. 1B). In general, cells had a large central vacuole and a thin cytoplasm, and the plasmalemma and the tonoplast were in close proximity. The dark areas observed in the interior of the cells probably correspond to the presence of phenolic compounds that would have a significant affinity for the $\mathrm{OsO}_{4}$ used in the postfixation. In the cell wall, the cellulose microfibrils were clearly distinguished (by their light shades) embedded in a pectic matrix (which is dark shaded). The middle lamella was well defined.

Impacted tissue showed a great number of injured cells in the central region, approximately at 9 or $10 \mathrm{~mm}$ beneath the skin, but no cell wall rupture. The splitting of the middle lamella was observed in epidermal cells and in subjacent parenchyma cells, respectively (Fig. $2 \mathrm{~A}$ and $2 \mathrm{~B}$ ). In the inner part of the bruise, intense vesiculation appeared in the central vacuole (Fig. $2 \mathrm{C}$ ) and in the middle lamella region between cell walls of adjacent cells (Fig. 2D). Breakage of membranes was more appreciable in the parenchyma cells beneath the epidermis (Fig: 2B) than in the epidermis itself (Fig. 2A). Figure 2B shows the presence of disrupted mitochondria. Cell wall rupture was not observed.

Compressed tissues showed deformation, that is, a flattening in the direction of compression (Fig. 3A), which was more frequent in the central parewchyma of the section around 8 or $9 \mathrm{~mm}$ beneath the skin. Tonoplast breakage was observed (Fig. 3B), as was cell wall degradation (Fig. 3C), wherein some wall compounds were lost as vesiculation occurred. Deposits of unidentified material

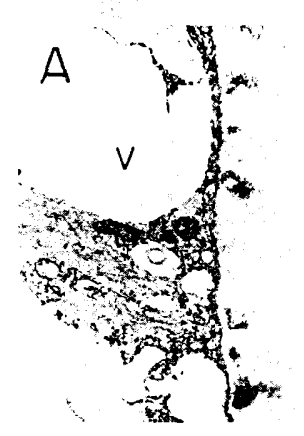

CW
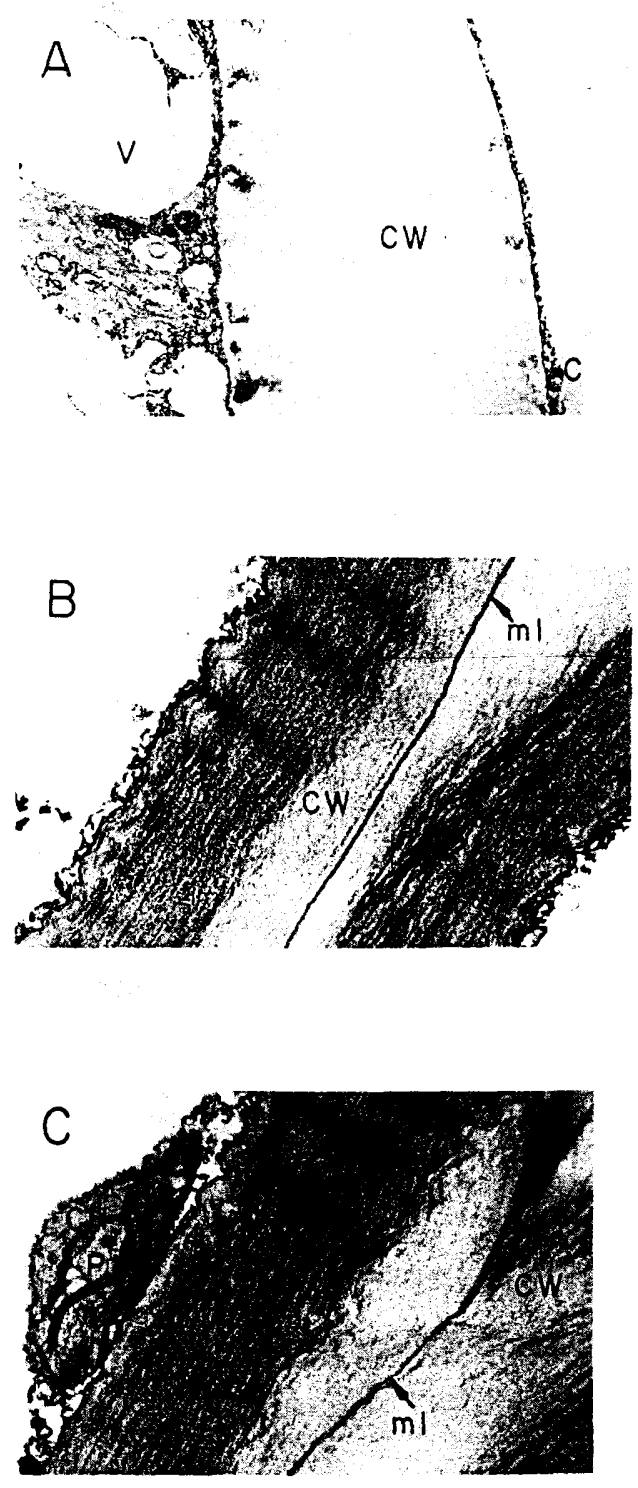

FIG. 1. TRANSVERSE SECTIONS OF PARENCHYMA CELLS FROM A NORMAL 'GRANNY-SMITH' APPLE A. Degraded cell wall and presence of a large vacuole and a thin cytoplasm, X 4,560. B. Cell wall and microfibrillar network and the neat presence of the middle lamella, X 10,260. C. Chromoplas with plastoglobule, X 10,260. C, cytoplasm; $\mathrm{CH}$, chromoplast; $\mathrm{CW}$, cell wall; ml, middle lamella $P$, plastoglobule; $V$, vacuole. 


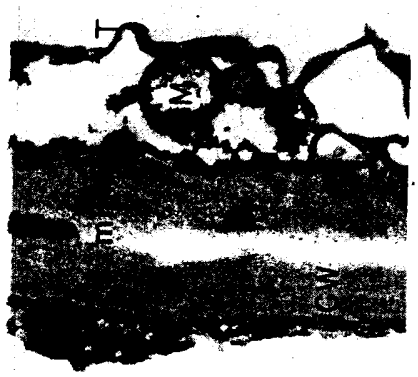

$m$

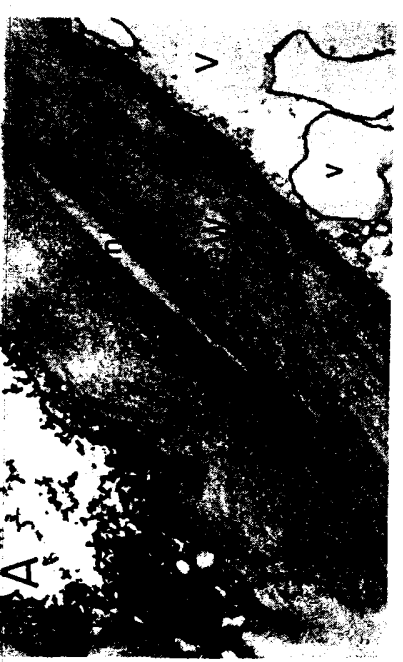

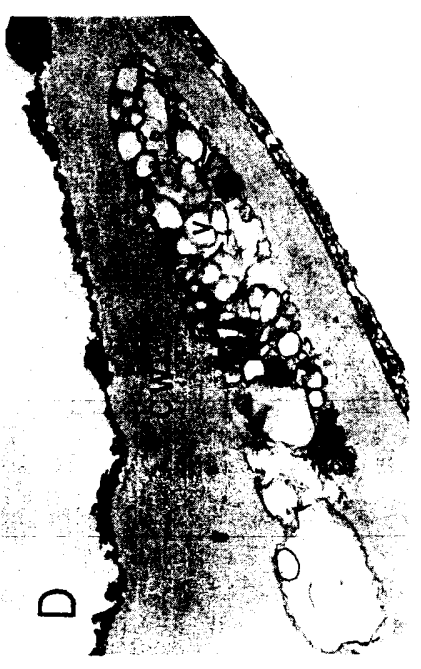
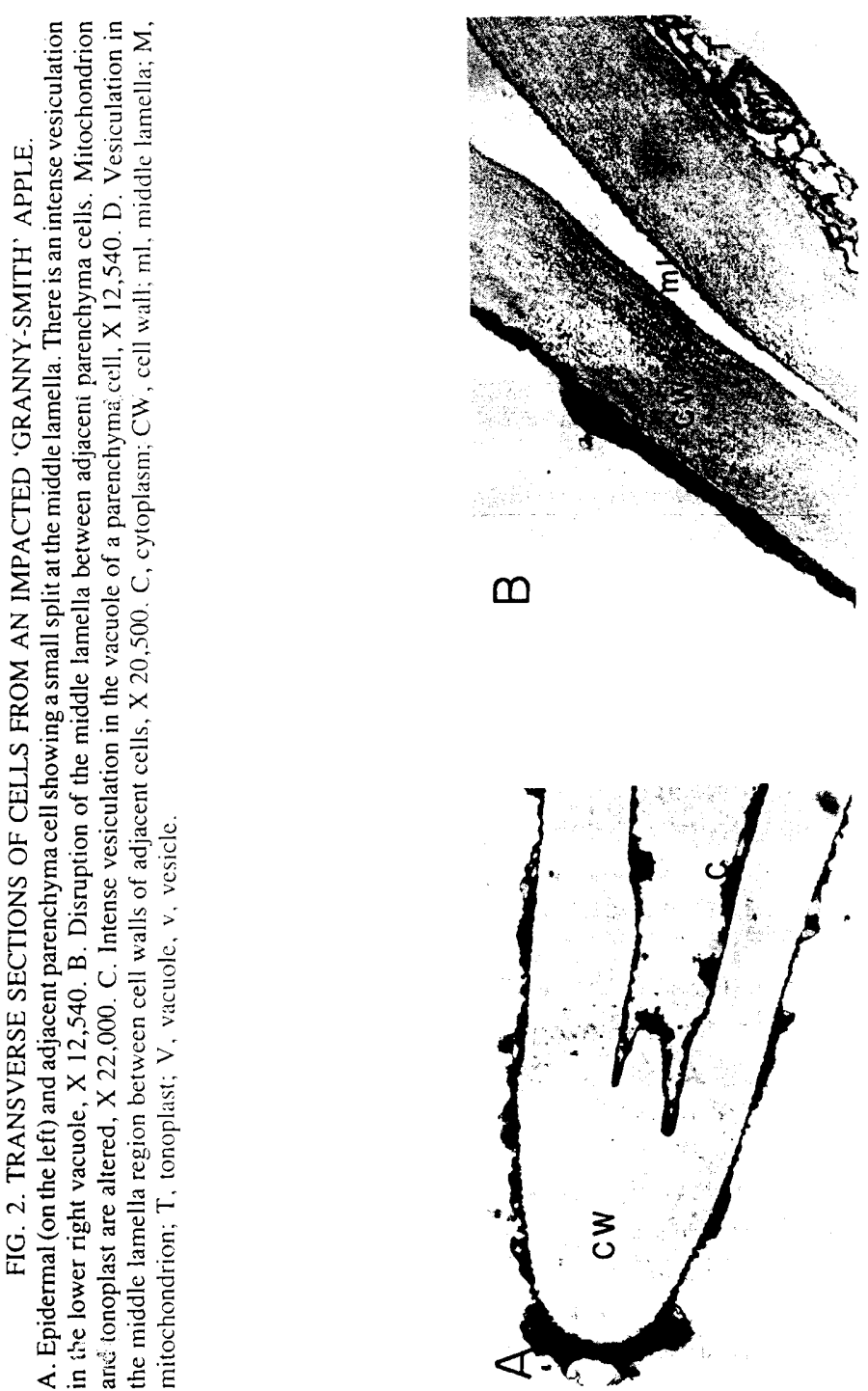
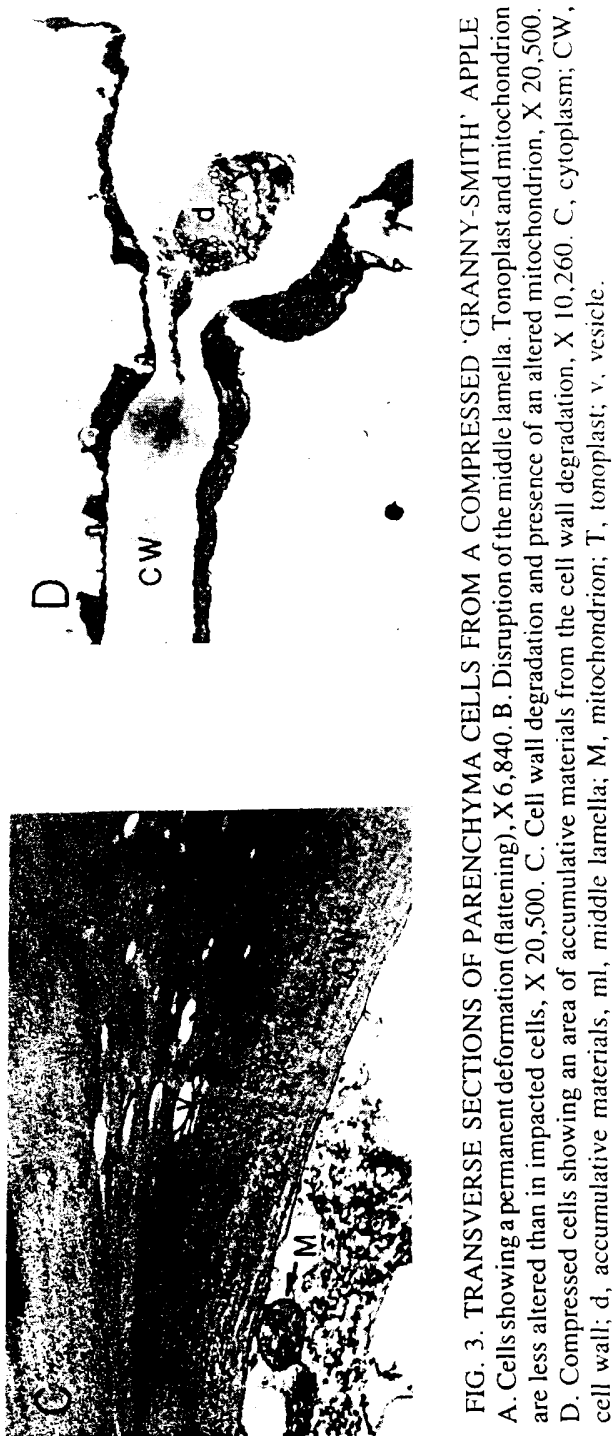
were seen in some areas of the central part of the bruise (Fig. 3D). Some of the cells located beneath the epidermis occasionally showed a split in the middle lamella region between adjacent cell walls (Fig. 3B). Cell wall rupture was not observed.

Parenchyma cells corresponding to a region adjacent to the bruising were not altered, and they resembled those seen in normal tissue.

\section{DISCUSSION}

A great number of altered cells are located in the parenchyma in the central region of an apple bruise, at a distance from the skin that approximately equals the indentor tip radius used to damage the fruit $(9-10 \mathrm{~mm})$. This observation supports the idea that it is in this region of the bruise where the maximum stress occurs as postulated by Horsfield et al. (1972) and Miles and Rehkugler (1971).

Stress supported by epidermal and hypodermal cells is less in comparison to that experienced by the interior parenchyma cells.

The fact that both kinds of bruises showed rupture of the tonoplast and plasmalemma but not of the cell wall, in the central area suggest that polyphenols and polyphenoloxidase meet somewhere in the altered cytoplasm or at the interface of the cell wall causing the browning reaction. Additionally the altered and broken membranes may leak these compounds from inside the ctil to the intercellular spaces, and thus the oxidative reaction may take place in the intercellular spaces as well. Thus, the browning reaction in fruit under applied loads can take place either outside or inside the cell. The rupture of the cell wall is not indispensable, at least in small bruises, for the reaction to succeed. This finding contradicts Diehl et al. (1979) and Pitt (1982) postulations that cell wall rupture is necessary.

The most noticeable differences observed in the structural response between apple tissues under impact and compression loads are the occurrence of an intense vesiculation in the vacuole and region between cell walls of adjacent parenchyma cells in the former case, often with the splitting of cell walls of adjacent cells. One possible hypothesis to explain the vesiculation observed in the vacuole under impact forces is that, due to the physical forces and momentum developed during impact load, the cytoplasm may pull back the vacuole, forming vesicles. Vesiculation observed in the cell wall is more difficult to explain. It is unlikely that a synthesis of cell wall enzymes occurs to cause degradation and vesicle formation because of the short time lapse (two hours) between the force application and the tissue fixation. Thus, it is logical to suggest that the type of stresses supported by the cell wall might play an important role in vesicles formation, perhaps by affecting calcium displacement.
Compressed cells show a deformation in the direction of the applied load, verifying the model postulated by Chen et al. (1986); Dal Fabro et al. (1980); Holt and Schoorl (1977 b); Nilsson et al. (1958); Pitt (1982); Segerlind and Dal Fabro (1978); where cells under slow loads (compression) undergo a change in shape, becoming smaller in the direction of the applied load as they begin to fill the intercellular spaces. The cell walls would behave elastically giving back part of the energy applied, keeping some permanent deformation (flattening shape). Compression forces play a role in displacing degradation materials of the cell wall from higher pressure areas to lower pressure areas.

The observations suggest that the nature of the stresses produced and the way that they develop in the tissues are different under compression and impact loads. Further research is required to clarify the cause of vesiculation and to deduce its trigger mechanism in the cell compounds under different stresses or strains produced by particular loads. Biochemical studies, including identification of enzymes and substrates, would be necessary to determine whether the browning reaction observed in fruits under different mechanical loads could be produced in different ways.

\section{REFERENCES}

BEN ARIE, and NAOMI, K. 1979. Ultrastructural changes in the cell walls of ripening apple and pear fruit. Plant Physiol. 64, 1979-202.

CHEN, P., RUIZ, M., LU, F. and KADER, A. A. 1986. Study of impact and compression damage on Asian pears. Trans. Am. Soc. Agr. Eng. Paper no. 86,3025

COOMBE, B. G. 1976. The development of fleshy fruits. Ann. Rev. Plant Physiol. 27, 507-528.

DAL FABRO, J. M. MURASE, H. and SEGERLIND, L. J. 1980. Strain failure of apple, pear and potato tissue. Trans. Am. Soc. Agr. Eng. Paper no. 80, 3025.

DIEHL, K. C., HAMAN,; D. D. and WHITFIELD, J. K. 1979. Structural failure in selected raw fruit and vegetables. J. Text. Stud. 10, 371-400.

FAUST M. and SHEAR, C. B. 1968. Corking disorders of apples: A physiological and biochemical review. Bot. Rev. 34, 441-469.

GARCIA, C. R. 1988. Impacto mecanico en frutos. Ph.D. Dissertation, Universidad Politecnica de Madrid. Spain. pp. 273-280.

GARCIA, C. R., RUIZ, M. and CHEN, P. 1988. Impact parameters related to bruising in selected fruits. Trans. Am. Soc. Agr. Eng. Paper no. 88, 6027.

HOLT, J. E. and SCHOORL, D. 1977a. Bruising and energy dissipation in apples. J. Text. Stud. 7, 421-432. 
HOLT, J. E. and SCHOORL, D. 1977b. The effect of storage time and temperature on the bruising of Jonathan, Delicious and Granny Smith apples. J. Text. Stud. 6, 409-416.

HORSFIELD, B. D., FRIDLEY, R. B. and CLAYPOOL, L. L. 1972. Application of elasticity to the design of fruit harvesting and handling equipment for minimum bruising. Trans. Am. Soc. Agr. Eng. Paper no. 15, 746-749.

HYDE, J. F. and INGLE, M. 1968. Size of apple bruises as affected by cultivar, maturity and time in storage. Proc. Amer. Soc. Hort. Sci. 92, 733-738.

JARYMOPAS, B. 1984. Failure of apples under dynamic loading. Research Thesis. Faculty of Agricultural Engineering. Institute of Technology. Haifa, Israel.

MILES, I. A. and REHKUGLER, G. E. 1971. The development of failure criterion for apple flesh. Trans. Am. Soc. Agr. Eng. Paper no. 16, 11481153.

NILSSON, S. B., HERTZ, C. N. and FALK, S. 1958. On the relation between turgor pressure and tissue rigidity II. Physiologia Plantarum. 11, 818-837.

O'BRIEN, M., SINGH, R. P. and GARRET, R. E. 1983. The effect of bruising on dried fruit quality. Am. Soc. Agr. Eng. Paper no. 83, 6010.

PITT, R. E. 1982. Models for the rheology and statistical strength in stressed vegetative tissue. Trans. Am. Soc. Agr. Eng. Paper no. 25, 1776-1984.

REYNOLDS, E. S. 1963. The use of lead citrate at high $\mathrm{pH}$ as an electron opaque stain in electron microscopy. J. Cell. Biol. 17, 208-213.

RODRIGUEZ, L. 1988. Reaccion a la magulladura producida en frutos: estudio fisiologico, histologico, mecanico y tecnicas para su evaluacion. Ph.D. dissertation. Universidad Politecnica de Madrid. Spain. pp. 189-202.

SEGERLIND, L. J. and DAL FABRO, J. 1978. A failure criterion for apple flesh. Trans. Am. Soc. Agr. Eng. Paper no. 78, 3558.

SHOEI, Y. 1984. Isolation of vacuoles from immature apple fruit flesh and compartmentation of sugars, organic acids, phenolic compounds and amino acids. Plant Cell Physiol. 25, 151-166.

TOPPING, A. J. and LUTON, M. J. 1986. Cultivar differences in the bruising of English apples. J. Hort. Sci. 61, 9-13.

VAMOS-VIGYAZO, L. 1981. Polyphenol oxidase and peroxidase in fruits and vegetables. CRC. Critical Reviews in Food Science and Nutrition. Set. pp. $49-127$. 